\title{
BUDIDAYA BUAH-BUAHAN DI PEMATANG TAMBAK UNTUK MENINGKATKAN KESEJAHTERAAN WARGA DESA SAWOHAN
}

\author{
Soffil Widadah, Achmad Dhany Fachrudin \\ STKIP PGRI Sidoarjo \\ E-mail: soffdah16@gmail.com,dh4nyy@gmail.com
}

\begin{abstract}
The purpose of KKN-PPM is to improve the welfare of the Sawohan village community in Buduran sub-district. The average size of fish ponds' embankment in Sawohan village are 4-8 meters in wide, larger than the other. The utilization of course must consider the selection of fruit types, because there are several types of fruits that can survive in hot areas and the results are better when doused with salt water, such as golden cucumber and garbis. Tilted ponds are very beneficial as the flow of rainwater. In addition, a green house was made as an experiment to provide fruit resistance to extreme weather in ponds. In addition, an irrigation system that is sourced from river water is made with the aim of alleviating farmers. water channels as a stream of rainwater so as not to overflow. This method of implementing KKN-PPM starts with debriefing students from experienced farmers. Furthermore, the implementation and practice of planting in ponds and providing education to residents by conducting socialization and seminars. It is expected that the villagers will be motivated and willing to practice. The last hope is that the welfare of the Sawohan village community in Buduran sub-district, Sidoarjo district can be improved.
\end{abstract}

Keywords: Embankment of fishpond, Fruit Cultivation, Life Welfare

\section{PENDAHULUAN}

Desa Sawohan terletak di sisi timur kabupaten Sidoarjo ini memiliki luas desa mencapai $914.194 \mathrm{Ha}$, dan 40 persen di antaranya wilayah tambak. Desa Sawohan berada pada ketinggian empat meter dari permukaan laut dengan curah hujan sebesar $2000 \mathrm{~mm} /$ th dan suhu udara rata-rata 30oC. Tak heran, banyak penduduk desa yang menggantungkan hidupnya pada tambak.

Menurut Mauluddin (salah satu warga desa Sawohan), awal mula munculnya penyakit udang pada awal tahun 1990-an. Waktu itu, masyarakat Desa Sawohan sangat bergantung pada hasil tambak. Malah saat itu untuk mencari orang dengan pekerjaan lain, sangatlah sulit. Mereka bisa hidup berkecukupan hanya dengan hasil tambak. Kondisi

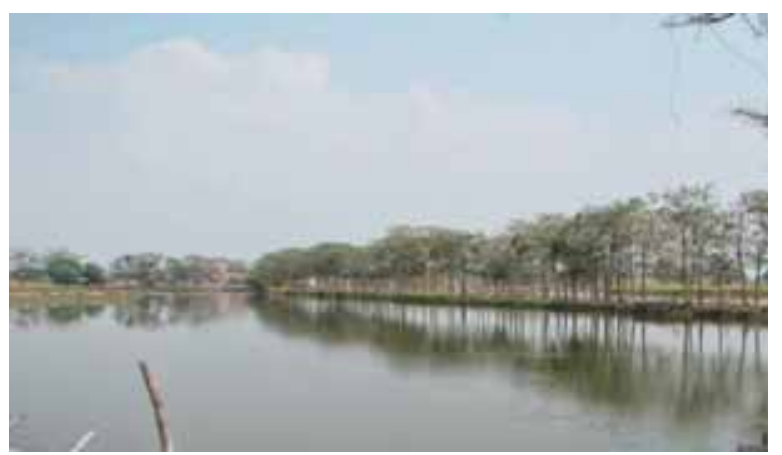

Gambar 1. Daerah Tambak Desa Sawohan itu berubah ketika udang-udang desa Sawohan terserang penyakit. Waktu itu, ada beberapa petani yang memanen udang-udangnya lebih awal agar tidak terserang penyakit. "Meski demikian, dulu hasilnya masih lumayan. kami masih bisa untung," tutur Mauluddin.

Selain karena penyakit, berkurangnya hasil panen tambak di Sawohan juga kurangnya pengelola atau buruh tambak yang mau merawat. Kebanyakan mereka yang masih bertahan menjadi petani tambak atau buruh tambak adalah para orang tua. Sedangkan pemuda yang memiliki lebih banyak stamina dan tenaga memilih menjadi buruh pabrik atau bekerja serabutan di luar desa.

Beragam alasan, seperti upah yang didapat saat bekerja sebagai buruh pabrik lebih besar ketimbang bekerja di tambak. Hitungannya, jika bekerja di tambak dari pagi hingga sore, mereka menerima upah Rp 70 ribu. Tetapi upah itu belum tentu bisa didapatkan setiap hari. Berbeda jika bekerja sebagai buruh pabrik, setiap hari bisa mendapat upah Rp 50 ribu. "Bekerja di tambak itu hasilnya nggak bisa diandalkan, soalnya kerjanya tidak tentu," kata Thoriq, pemuda Desa Sawohan yang bekerja di sebuah pabrik di Buduran. Banyak orang tua yang melarang anaknya bekerja di tambak.

Akhirnya, karena dalam beberapa tahun terakhir mengalami penurunan, banyak petani tambak yang beralih profesi. Mereka mencari pekerjaan lain sebagai sambilan agar bisa memenuhi kebutuhan, meski sesekali menggarap tambak. Ada pula yang meninggalkan tambak dan bekerja sebagai buruh pabrik dan pekerjaan lainnya. 


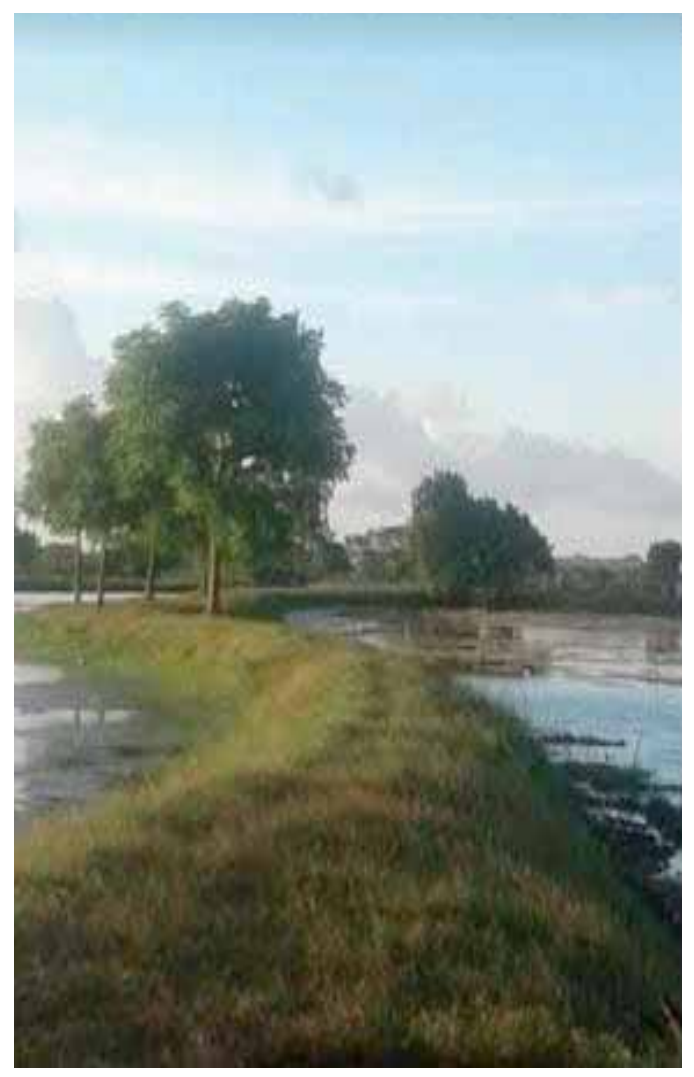

Gambar 2. Pematang Tambak Desa Sawohan

Sebenarnya para buruh tambak bisa memanfaatkan pematang tambak untuk menanam berbagai macam buahbuahan untuk menambah penghasilan. Berdasarkan observasi dan wawancara dengan Munfatik (Kepala Desa Sawohan), pematang tambak tambak di desa Sawohan berbeda dengan pematang tambak yang ada di desa-desa lain. Pematang tambak di desa Sawohan jauh lebih lebar daripada pematang tambak yang ada di desa lain. Jika di desa lain lebar pematang tambak hanya sekitar 1,5 meter, maka di desa Sawohan lebar pematang tambak 4-8 meter. Hal ini sangat memungkinkan untuk melakukan budidaya buah-buahan yang hasilnya dapat meningkatkan kesejahteraan masyarakat khususnya para buruh tambak. Namun mereka enggan melakukan hal tersebut dengan alasan biaya yang mahal. Sedangkan para pemilik tambak tidak punya banyak waktu untuk melakukan budidaya buah-buahan di pematang tambak yang mereka miliki.

\section{Permasalahan Mitra}

1. Bagaimana masyarakat desa Sawohan, kecamatan Buduran, kabupaten Sidoarjo dapat meningkat kesejahteraannya?

2. Bagaimana cara pemberdayaan masyarakat agar budidaya buah-buahan bisa berkelanjutan?

\section{PENDEKATAN/ METODE YANG DIGUNAKAN}

Buah-buahan akan ditanam pada sisi kana dan kiri pematang tambak. Ada beberapa jenis buah-buahan yang bisa bertahan di daerah panas, bahkan hasilnya lebih baik apabila disiram dengan air asin. Oleh karena itu penyiraman dilakukan dengan memompa air tambak dan dialirkan untuk menyiram tumbuhan buah-buahan. Untuk melindungi buah-buahan dari air hujan akan dibuat green house, karena buah-buahan yang tahan panas biasanya tidak tahan dengan air hujan atau mudah busuk apabila terkena air hujan. Selain itu, dibuat aliran-aliran air agar air hujan tidak menggenang yang bisa merusak buah-buahan. Adapun cara penanaman sebagai berikut:

a. Harus mengetahui syarat tumbuh, yakni tanah harus banyak mengandung unsur hara

b. Penyemaian Benih dan Persiapan Bibit, yakni menggunakan polybag atau tray semai

c. Persiapan Lahan Tanam, lahan dibersihkan kemudian dibuat bedengan

d. Pemupukan Dasar, dilakukan sebelum benih disemai di tray semai

e. Penanaman buah-buahan, dilakukan setelah bibit berumur 10-14 hari

f. Penyiraman

g. Penyulaman, penggantian tanaman yang mati atau tumbuh tidak sempurna

h. Penyiangan

i. Pemupukan susulan, dilakukan saat tanaman berumur sekitar 15 hari

j. Penyemprotan hama dan penyakit tanaman buahbuahan

\section{k. Pemanenan}

Buah-buah yang sudah dapat dipanen apabila buah telah berumur sekitar 50 hari. Dalam sekali tanam, pemanenan dapat dilakukan sebanyak 2 sampai 3 kali.

\section{PEMBAHASAN}

Buah-buahan (semangka, blewah, dan timun emas) ditanam pada pematang tambak. Penyiraman dilakukan dengan memompa air tambak dan dialirkan untuk menyiram tumbuhan semangka, blewah, dan timun emas. Penyiraman menggunakan spingkle. Pembuatan green house untuk melindungi buah-buahan dari air hujan, karena buah-buahan yang tahan panas biasanya tidak tahan dengan air hujan atau mudah busuk apabila terkena air hujan. Selain itu, dibuat aliran-aliran air agar air hujan tidak menggenang yang bisa merusak buah-buahan. 


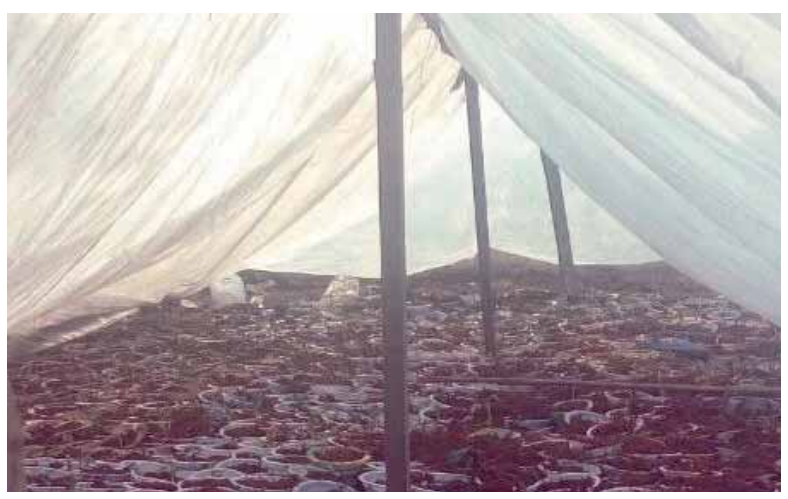

Gambar 3. Penyemaian Benih

Adapun cara penanaman sebagai berikut:

a. Syarat Tumbuh

Tanah yang digunakan untuk menanam buahan-buahan ini harus kaya akan unsur hara dan memiliki $\mathrm{pH}$ sekitar 6,0 hingga 7,0 .

b. Penyemaian Benih dan Persiapan Bibit Benih dapat ditanam langsung dalam lahan tanam, 1 hingga 2 benih per lubang tanam, tapi lebih baik lakukan penyemaian benih terlebih dahulu, penyemaian dapat menggunakan polybag atau tray semai. Tetapi dalam hal ini, peserta KKN-PPM memanfaatkan gelas plastik bekas sebagai tray semai. Sebelum disemai, bibit dijemur kemudian direndam sampai biji berkecambah, apabila sudah berkecambah maka biji siap ditanam. Sebelum benih disemaikan, gelas plastik diberi tanah yang telah dicampur dengan pupuk urea. Benih disemaikan, kemudian ditutup dengan sekam yang telah disiram dengan air. Setelah berumur 10 hingga 14 hari bibit dapat dipindahtanamkan ke lahan tanam.

c. Persiapan Lahan Tanam

Lahan yang akan digunakan untuk budidaya, dibersihkan dahulu dari rumput liar atau tanaman pengganggu lainnya. Pemberihan rumput dilakukan dengan dua cara, yaitu ada yang secara manual oleh mahasiswa, ada yang menggunakan alat pemotong rumput. Selanjutnya menggemburkan tanah dengan cara dibajak atau dicangkul. Lahan yang telah dibersihkan dibiarkan selama kira-kira 15 hari untuk meminimalisir tumbuhnya

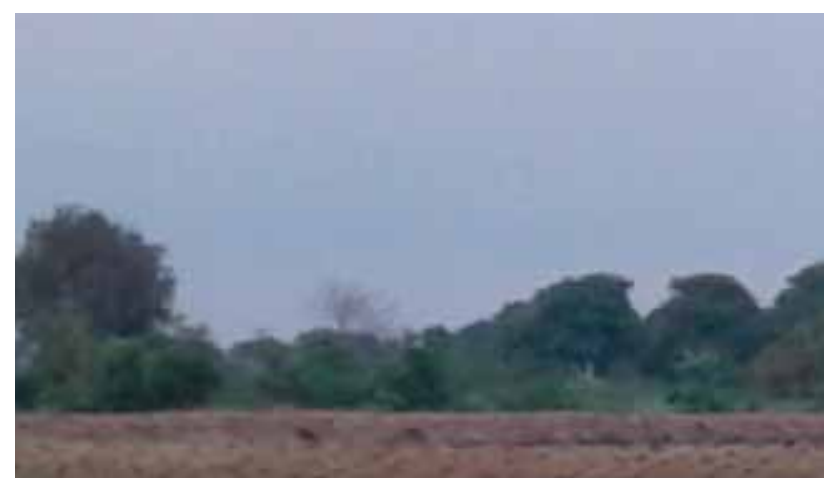

Gambar 4. Lahan Tanam yang sudah dicuklak rumput, kemudian disemprot menggunakan sidapos atau gramashon agar rumput tidak tumbuh. Selanjutnya membuat bedengan dengan ukuran bedengan sekitar 60 hingga $80 \mathrm{~cm}$ untuk lebarnya dan memiliki lebar parit sekitar $40 \mathrm{~cm}$ Serta jarak antar bedengan 2 hingga 3 meter (untuk menjalar batang tanaman)

d. Pemupukan Dasar

Apabila bedengan telah selesai dibuat, selanjutnya dilakukan pemupukan dasar menggunakan pupuk kandang atau kompos, NPK aatu campuran KCL, ZA, dan TSP atau SP36. Seminggu sebelum melakukan pemupukan dasar, dilakukan pengapuran menggunakan pupuk pertanian atau dolomit jika $\mathrm{pH}$ tanah kurang dari 6.0. Setelah pengapuran, ditaburkan sekitar $1 \mathrm{~kg}$ pupuk kandang dan $250 \mathrm{~g}$ pupuk NPK /lubang tanam. Selanjutnya bedengan ditutup menggunakan mulsa plastik agar kelembapan tanah tetap terjaga dan juga untuk meminimalkan tumbuhnya gulma. Setelah itu, membuat lubang tanam dengan jarak antar lubang sekitar 60-70 cm.

e. Penanaman blewah, semangka, dan timun emas

Penanaman paling bagus pada saat pergantian musim hujan ke musim kemarau. Setelah bibit berumur 10-14 hari dan lahan tanam pun sedah siap, segera lakukan penanaman. Benih yang dipilih adalah benih yang sehat, memiliki vigor yang kuat dan tidak cacat. Sebelum bibit ditanam, lubang tanam disiram terlebih dahulu sampai basah, selanjutnya tugal dengan kedalaman yang disesuaikan dengan polybag semai, jika selesai, polybag dilepas kemudian bibit dimasukkan beserta media tanam dalam lubang tanam. Selanjutnya penyiraman bibit secukupnya. Penanaman ini baik dilakukan pada sore hari. Ketika tanaman telah tumbuh, rumput yang ada di sekitar tanaman harus dibersihkan, kemudian mendangir agar sirkulasi air dan udara lancar.

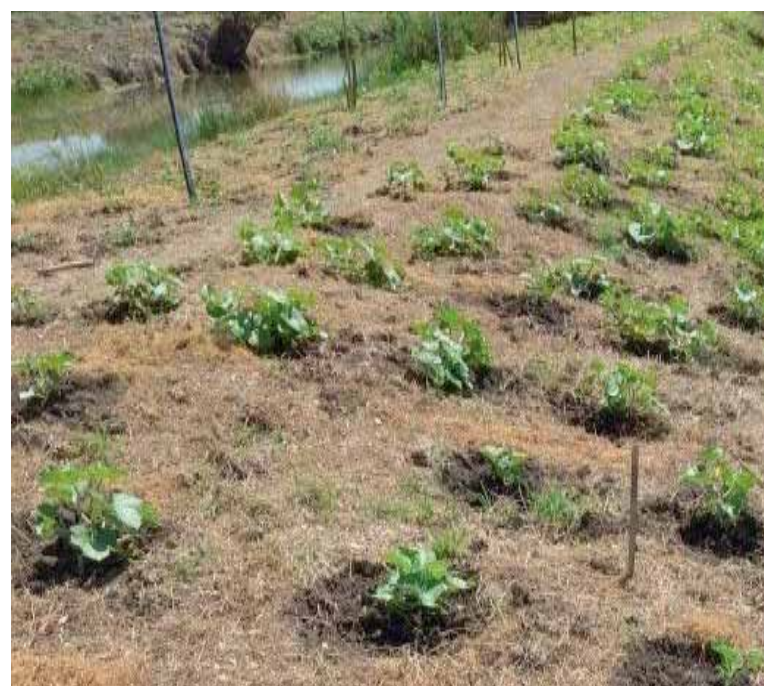

Gambar 5. Pematang Tambak yang Telah Ditanami Buahbuahan 
f. Penyiraman

Pada saat bibit berumur 0 hingga 10 hari, penyiraman dilakukan setiap hari, selanjutnya dilakukan sesuai kebutuhan biasanya $2 / 3$ hari sekali.

g. Penyulaman

Penyulaman atau penggantian dilakukan pada bibit yang mati atau tumbuh tidak sempurna. Penyulaman ini dapat dilakukan hingga bibit berumur 21 hari setelah tanam.

h. Penyiangan

Penyiangan dilakukan pada rumput yang tumbuh disekitar lubang tanam dan juga parit. i. Pemupukan Susulan Pemupukan susulan pertama dilakukan saat tanaman berumur sekitar 15 hari setelah tanam, pemupukan tersebut dilakukan menggunakan pupuk NPK, TSP, $\mathrm{ZA}$, dan $\mathrm{KCl}$. Pemupukan tersebut iberikan dengan cara dikocor ataupun ditabur. Pupuk Urea diberikan 4 kali yaitu ketika penanaman umur 0, 15, 30, 45 hari: Pupuk ZA diberikan 3 kali yaitu umur 15, 30 dan 45 hari; pupuk TSP diberikan 3 kali yaitu umur 15, 30, dan 45 hari; Obat pembesar buah (KNO) diberikan 2 kali yaitu umur 30 dan 45 hari; Obat daun (demathon) dan super flora diberikan tergantung kondisi.

j. Hama dan Penyakit Tanaman Buah-buahan Hama dan penyakit yang sering menyerang tanaman blewah antara lain jangkrik, ulat grayak, oteng-oteng, lalat buah, ulat buah, penyakit bercak daun, layu, bokur (kumbang kecil merah yang merusak daun), walang sangit (merusak daun), ulat (merusak daun dan buah, biasanya yang diserang daun muda), kerapak merupakan jenis virus tanaman yang paling merusak daun. Selain itu, udara dingin dan perubahan cuaca akan mempengaruhi perkembangan buah-buahan. Hama yang menyerang dapat diatasi dengan penggunaan insektisida yang sesuai sedangkan untuk penyakit dapat diatasi dengan menggunakan fungisida yang sesuai. Obat hama yang digunakan antara lain: desis, prematon, ridomil, dan komidor.

k. Pemanenan

Buah-buahan dapat dipanen apabila telah berumur sekitar 50 hari. Dalam sekali tanam, pemanenan blewah dapat dilakukan sebanyak 5 sampai 6 kali, sedangkan semangka dan timun emas dapat dilakukan 2 sampai 3 kali. Pemanenan dilakukan bersama-sama, yaitu warga, mahasiswa, dan dosen. Panen raya ini dilakukan dua kali, yaitu hari Minggu tanggal 20 Mei 2018 dan hari Sabtu tanggal 26 Mei 2018. Panen pertama menghasilkan 950 $\mathrm{kg}$ blewah, sedangkan panen kedua menghasilkan 850 $\mathrm{kg}$ blewah, $100 \mathrm{~kg}$ timun emas, dan $100 \mathrm{~kg}$ semangka. Panen selanjutnya dilakukan kondisional, apabila ada buah yang sudah layak panen langsung di panen dan dititipkan di penjual buah di pasar, tidak lagi melalui tengkulak ataupun pengepul.

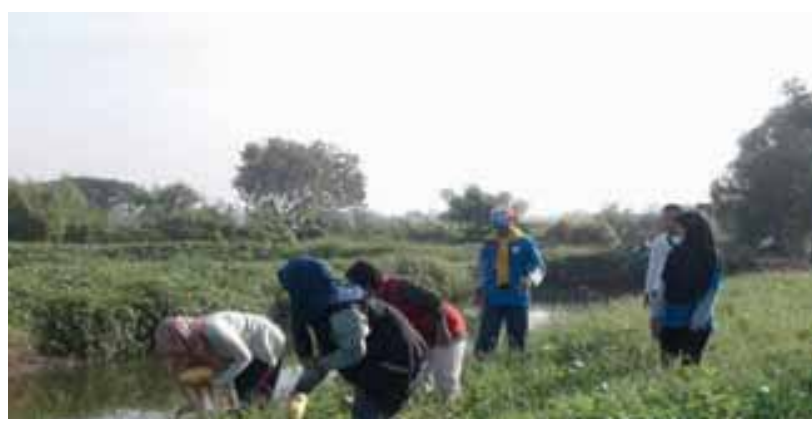

Gambar 6. Panen Raya (Dosen, Mahasiswa, dan Warga)

\section{PENUTUP}

\section{Kesimpulan}

Tingkat kesejahteraan masyarakat desa Sawohan dapat ditingkatkan memanfaatkan pematang tambak untuk budidaya buah-buahan. Dengan demikian pematang tambak tidak hanya berfungsi sebagai jalan atau tempat memancing saja. Perawatan dan pemeliharaan dapat dilakukan dengan membentuk organisasi pengelola budidaya buah-buahan, sehingga petani bisa memperoleh arahan lanjutan dari Dinas Pangan dan Pertanian.

\section{Saran}

Sebaiknya para petani tambak tidak hanya membudidayakan blewah, semangka, dan timun emas saja di pematang tambak, tetapi bisa dikembangkan dengan menanam jenis buah-buahan lain atau bahkan sayur-sayuran yang bisa bertahan hidup di daerah panas.

\section{DAFTAR PUSTAKA}

Hartadi, R. W. (1979). Aspek Sosial-Budaya Masyarakat Tani Tambak Dikabupaten Sidoarjo

Hidayanto, M., Timur, B. P. T. P. K., Noor-Sempaja, J. P., \& Heru, W. (2014). Analisis tanah tambak sebagai indikator tingkat kesuburan tambak

https://id.wikipedia.org/wiki/Sawohan,_Buduran,_Sidoarjo http://sid.sidoarjokab.go.id/buduran-Sawohan/index. $\mathrm{php} /$ first/artikel/32.

Rukmana, I. H. R. (1994). Budi Daya Semangka Hibrida. Kanisius.

Yuniastin, B. W., \& Ujianto, L. (2018). Kajian Tingkat Keberhasilan Persilangan Antara Melon (Cucumis melo L) dengan BLEWAH (Cucumis melo var cantalupensis). CROP AGRO, Scientific Journal of Agronomy, 11(1), 33-39. 